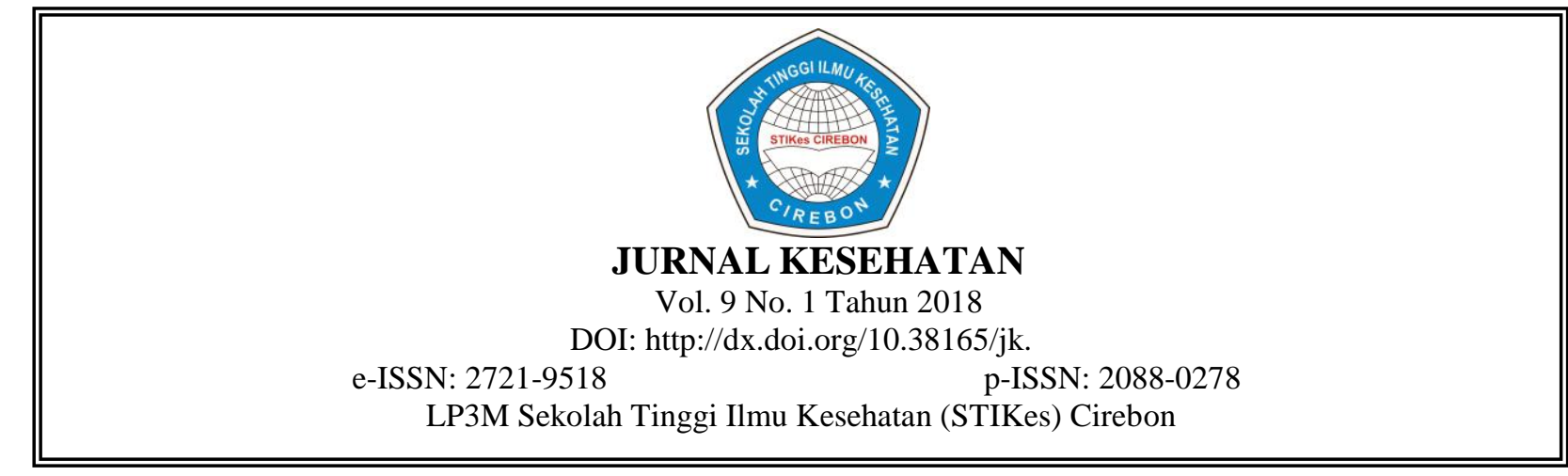

\title{
PENGARUH KUALITAS PELAYANAN LABORATORIUM TERHADAP TINGKAT KEPUASAN PASIEN
}

\author{
Destu Satya Widyaningsih* \\ Program Studi D3 Analis Kesehatan Manggala Yogyakarta \\ destu.satya@gmail.com \\ Novi Maryani*** \\ Program Studi D3 Analis Kesehatan Manggala Yogyakarta
}

\begin{abstract}
Abstrak
Kepuasan pasien merupakan penilaian pasien berdasarkan pelayanan yang diberikan. Indikator kepuasan pasien terhadap kualitas pelayanan dapat dilihat dari segi kinerja tenaga dokter, kinerja tenaga medis dan non medis, dan system administrasi. Pasien yang datang untuk periksa ke laboratorium Puskesmas Kotagede II mempunyai kaitan yang erat dengan hasil pelayanan kesehatan, baik secara medis maupun non medis. Berdasarkan hasil studi pendahuluan yang telah dilakukan oleh peneliti pada tanggal 31 desember 2016 didapatkan data rata-rata kunjungan pasien ke laboratorium Puskesmas Kotagede II dalam bulan November 2016 sebanyak 30 pasien perhari dan pada bulan desember 2017 rata-rata sebanyak 25 pasien perhari, terjadi penurunan kira-kira 16\% kunjungan pasien di laboratorium Puskesmas Kotagede II. Hal ini dapat mengindikasikan terjadinya penurunan kualitas pelayanan laboratorium di Puskesmas Kotagede II Kota Yogyakarta. Penelitian ini bertujuan untuk mengetahui tingkat kepuasan pasien di UPT Puskesmas Kotagede II Kota Yogyakarta. Jenis penelitian ini termasuk penelitian kuantitatif dengan pendekatan crossectional. Sampel penelitian berjumlah 122 responden. Analisa data menggunakan uji statistik korelasi rangking spearman yang ditinjau dari lima dimensi yaitu: Kehandalan (Realibility), Daya Tanggap (Responvinsiveness), Jaminan (Assurance), Empati (Empaty) dan Tampilan fisik (Tangible). Hasil penelitian pengaruh kualitas pelayanan laboratorium terhadap tingkat kepuasan pasien di UPT Puskesmas Kotagede II Kota Yogyakarta didapatkan hasil bahwa terdapat pengaruh kualitas pelayanan terhadap kepuasan pasien yang dibuktikan dengan nilai korelasi 0,417 dan nilai signifikansi 0,022 yang lebih kecil dari 0,05.
\end{abstract}

Kata Kunci: Kualitas Pelayanan Laboratorium, Kepuasan Pasien

\begin{abstract}
Patient satisfaction is defined as patient assessment towards the service they received. Indicators for patient satisfaction regarding quality of service can be observed from the performance of medical doctors and other health professionals, as well as administration system. Patients seeking services from laboratory unit of Kotagede II Primary Health Care $(P H C)$ is highly associated with the results of health service, both medical and non-medically. According to preliminary study conducted by the author on 31 December 2016, average number of patients visiting Kotagede II PHC were 30 patients and 25 patients per day on November and December 2016, respectively. The results demonstrated approximately $16 \%$ decline in patient visits to the laboratory unit. This may be due to decrease in quality of service in Kotagede II PHC. The research was conducted to understand the level of patient satisfaction in laboratory integrated service unit of Kotagede II PHC, Yogyakarta, in year 2017. The research was a quantitative study with cross sectional approach. Total number of respondents was 122 persons. Data analysis was performed by using Spearman's rank correlation statistical test, analyzed from five aspects: reliability, responsiveness, assurance, empathy, and tangible.

The results showed that there was a correlation between quality of health service with patient satisfaction in laboratory integrated service unit of Kotagede II PHC, as shown by correlation value of 0.417 and significance level of 0.022 $(<0.05)$.
\end{abstract}

Keywords: quality service, laboratory, patient satisfaction 


\section{PENDAHULUAN}

Puskesmas memiliki peran penting dalam upaya meningkatkan derajat kesehatan masyarakat sesuai dengan keinginan dan kebutuhan pasien yang mengacu pada kode etik profesi dan medis. Puskesmas adalah unit pelaksana teknis dinas kesehatan kabupaten atau kota yang bertanggung jawab menyelenggarakan pembangunan kesehatan di wilayah kerja tertentu. ${ }^{1}$

Peningkatan kualitas pelayanan juga dilakukan pada pemeriksaan penunjang dalam hal ini adalah pelayanan laboratorium. Pelayanan laboratorium dilakukan untuk mendapatkan informasi tentang kesehatan perorangan terutama untuk menunjang diagnosis penyakit, penyembuhan penyakit dan pemulihan penyakit. ${ }^{2}$

Puskesmas Kotagede II Kota Yogyakarta dituntut untuk selalu menjaga kepercayaan dan kepuasan pasien dengan meningkatkan kualitas pelayanan agar kepuasan pasien meningkat. Pihak Puskesmas Kotagede II secara cermat menentukan kebutuhan pasien sebagai upaya untuk memenuhi harapan atau keinginan dan meningkatkan kepuasan atas pelayanan yang diberikan. Pasien yang datang untuk periksa ke laboratorium Puskesmas Kotagede II mempunyai kaitan yang erat dengan hasil pelayanan kesehatan, baik secara medis maupun non medis. Berdasarkan hasil studi pendahuluan yang telah dilakukan oleh peneliti pada tanggal 31 desember 2016 didapatkan data rata-rata kunjungan pasien ke laboratorium Puskesmas Kotagede II dalam bulan November 2016 sebanyak 30 pasien perhari dan pada bulan desember 2017 rata-rata sebanyak 25 pasien perhari, terjadi penurunan kira-kira 16\% kunjungan pasien di laboratorium Puskesmas Kotagede II. Hal ini dapat mengindikasikan terjadinya penurunan kualitas pelayanan laboratorium di Puskesmas Kotagede II.

Dari uraian di atas sangatlah perlu dilakukan penelitian tentang sejauhmana Pengaruh Kualitas Pelayanan Laboratorium Terhadap Tingkat Kepuasan di UPT Puskesmas Kotagede II Tahun 2017. Tujuan dari penelitian ini adalah untuk mengetahui tingkat kepuasan pasien terhadap pelayanan laboratorium di Puskesmas Kotagede II Kota Yogyakarta Tahun 2017.

Kualitas pelayanan adalah kesesuaian pelayanan kesehatan dengan standar profesi dan memanfaatkan sumber daya yang ada secara baik, sehingga semua kebutuhan pelanggan dan tujuan untuk mencapai derajat kesehatan yang optimal dapat tercapai. ${ }^{3}$

Konsep penelitian tentang kepuasan pasien dapat dinilai dari konsep lima dimensi mutu atau kualitas pelayanan yang dikenal sebagai service quality. ${ }^{4}$

1. Dimensi tampilan fisik (Tangibel) yang diberikan kepada pelanggan sepeti fasilitas fisik, perlengkapan, keramahan, akan mempengaruhi tingkat loyalitas pelanggan.

2. Dimensi kehandalan (Reliability) dari pelayanan yang diberikan oleh laboratorium dalam bentuk kecepatan, keakuratan dan memuaskan akan berdampak tingginya loyalitas pelanggan terhadap kinerja di laboratorium.

3. Dimensi daya tanggap (Responsiveness) para petugas laboratorium dalam melayani pelanggan. Ketika pelayanan yang baik diberikan oleh petugas laboratoium akan terbentuk hubungan keluarga sehingga terjalinnya komunikasi yang baik dan efektif.

4. Dimensi jaminan (Assurance) mencakup pengetahuan, kemampuan, kesopanan dan sifat dapat dipercaya oleh pelanggan.

5. Dimensi empati (Empaty) berkaitan dengan pemberian perhatian penuh kepada konsumen, pemahaman akan kebutuhan pasien, perhatian terhadap kepentingan pasien dan juga kesesuaian waktu pelayanan dengan kebutuhan pasien.

Kepuasan pasien adalah hasil penilaian pasien berdasarkan perasaanya, terhadap penyelenggaraan pelayanan kesehatan. indikator pelayanan kesehatan yang dapat menjadi prioritas menentukan kepuasan pasien, diantaranya adalah seperti berikut. ${ }^{5}$ :

1. Kinerja tenaga dokter, adalah prilaku atau penampilan dokter rumah sakit dalam proses pelayanan kesehatan pada pasien, yang meliputi ukuran: layanan medis, layanan nonmedis, tingkat kunjungan, sikap, dan penyampaian informasi. 
2. Kinerja tenaga perawat, adalah perilaku atau penampilan tenaga perawat rumah sakit dalam proses pemberian pelayanan kesehatan pada pasien, yang meliputi ukuran: layanan medis, layanan non medis, sikap, penyampaian informasi, dan tingkat kunjungan.

3. Kondisi fisik, adalah keadaan sarana puskesmas dalam bentuk fisik seperti ruangan UGD, jendela, pengaturan suhu, ruang tunggu, dan halaman parkir yang luas.

4. Sistem administrasi pelayanan, adalah proses pengaturan atau pengelolaan pasien di puskemas yang harus diikuti oleh pasien (rujukan dan biasa), mulai dari kegiatan pendaftaran sampai rujukan kerumah sakit.

5. Pembiayaan, adalah sejumlah uang yang harus dibayarkan kepada puskesmas selaras pelayanan yang diterima oleh pasien, seperti biaya dokter, obat-obatan, makan, dan kamar. Rekam medis, adalah catatan atau dokumentasi mengenai perkembangan.

6. Kondisi kesehatan pasien yang meliputi diagnosis perjalanan penyakit, proses pengobatan dan tindakan medis, dan hasil pelayanan.

\section{METODE PENELITIAN}

Jenis desain penelitian ini menggunakan desain penelitian kuantitatif dengan pendekatan cross sectional). Penelitian ini untuk melihat pengaruh kualitas pelayanan laboratorium terhadap tingkat kepuasan pasien di UPT Puskesmas Kotagede II Kota Yogyakarta Tahun 2017. Populasi pada penelitian ini adalah semua pasien yang memeriksakan ke bagian Laboratorium di UPT Puskesmas Kotagede II Kota Yogyakarta Tahun 2017. Berdasarkan studi pendahuluan yang telah dilakukan oleh peneliti didapatkan rata-rata populasi sebanyak 175 pasien. Jumlah sampel yang dipakai dalam penelitian menggunakan rumus Soekidjo Notoatmodjo, 2010. Adapun rumusnya sebagai berikut:

$$
\mathrm{n}=\frac{N}{1+0,005^{2} x N}
$$

Keterangan:

$\mathrm{n}$ : Sampel yang diinginkan

$\mathrm{N}$ : jumlah populasi

Dari rumus tersebut dapat diketahui jumlah sampel yang dibutuhkan dalam penelitian ini adalah:

$$
\begin{aligned}
& \mathrm{n}=\frac{N}{1+0,005^{2} x N} \\
& \mathrm{n}=\frac{175}{1+0,005^{2} \times 175} \\
& \mathrm{n}=122 \text { sampel }
\end{aligned}
$$

Jadi sampel yang diperlukan dalam penelitian ini adalah 122 sampel

Data yang didapat berupa data primer dengan pengumpulan kuesioner dari responden setelah mendapatkan pelayanan laboratorium di Puskesmas Kotagede II. Subyek untuk data kuesioner penelitian ini yaitu responden yang telah mendapatkan pelayanan laboratorium dan bersedia mengisi lampiran kuesioner. Analisa data pada penelitian ini menggunakan uji statistik korelasi ranking spearman, yang digunakan untuk mengukuran erat-tidaknya antara dua (Supranto, 2001).

\section{HASIL PENELITIAN}

Hasil penelitian kualitas pelayanan tampilan fisik, kehandalan, daya tanggap, jaminan dan empati dalam mendukung kualitas pelayanan didapatkan hasil berikut dilihat pada tabel 1:

Tabel 1. Distribusi Frekuensi Kualitas Pelayanan

\begin{tabular}{ccccc}
\hline No. & Kualitas Pelayanan & Opsi Jawaban & Frekuensi & Persentase \\
\hline 1. & Tampilan Fisik & Setuju (Ya) & 79 & 64,7 \\
\hline
\end{tabular}




\begin{tabular}{|c|c|c|c|c|}
\hline & & Tidak Setuju (Tidak) & 43 & 35,3 \\
\hline \multicolumn{3}{|c|}{ Jumlah } & 122 & 100 \\
\hline \multirow[t]{3}{*}{2.} & Kehandalan & Setuju (Ya) & 73 & 59,8 \\
\hline & & Tidak Setuju (Tidak) & 49 & 40,2 \\
\hline & \multicolumn{2}{|c|}{ Jumlah } & 122 & 100 \\
\hline \multirow[t]{2}{*}{3.} & \multirow{2}{*}{ Daya Tanggap } & Setuju (Ya) & 66 & 54,1 \\
\hline & & Tidak Setuju (Tidak) & 56 & 45,9 \\
\hline \multicolumn{3}{|c|}{ Jumlah } & 122 & 100 \\
\hline \multirow[t]{3}{*}{4.} & \multirow[t]{2}{*}{ Jaminan } & Setuju (Ya) & 94 & 77,1 \\
\hline & & Tidak Setuju (Tidak) & 28 & 22,9 \\
\hline & \multicolumn{2}{|c|}{ Jumlah } & 122 & 100 \\
\hline \multirow[t]{3}{*}{5.} & \multirow[t]{2}{*}{ Empati } & Setuju (Ya) & 102 & 83,6 \\
\hline & & Tidak Setuju (Tidak) & 20 & 16,3 \\
\hline & \multicolumn{2}{|c|}{ Jumlah } & 122 & 100 \\
\hline
\end{tabular}

Berdasarkan tabel 1. bahwa sebagian besar responden menyatakan bahwa responden setuju dengan kualitas pelayanan tampilan fisik yang ada di laboratorium Puskesmas Kotagede II yaitu sebanyak 79 responden $(64 \%)$ dari 122 responden.

Hasil penelitian kualitas pelayanan kehandalan dalam mendukung kualitas pelayanan didapatkan hasil sebagian besar setuju bahwa kualitas kehandalan sudah baik. Hal ini menunjukkan bahwa sebagian besar responden menyatakan bahwa kualitas pelayanan kehandalan di Puskesmas Kotagede II sudah baik yaitu sebanyak 73 responden (59\%) dari 122 responden dan yang tidak setuju dengan kualitas pelayanan kehandalan sebanyak 49 reponden $(40,2 \%)$ ini dikarenakan jam buka laboratorium tidak sesuai dengan peraturan.

Hasil penelitian kualitas pelayanan daya tanggap dalam mendukung kualitas pelayanan didapatkan hasil sebagian besar setuju bahwa kualitas daya tanggap sudah baik. Hal tersebut menunjukkan bahwa sebagian besar responden menyatakan bahwa kualitas pelayanan daya tanggap di Puskesmas Kotagede II sudah baik yaitu sebanyak 73 responden (59\%) dari 122 responden dan yang tidak setuju dengan kualitas pelayanan daya tanggap sebanyak 56 responden $(45,9 \%)$ ini dikarenakan petugas kurang tanggap terhadap keluhan pasien.

Hasil penelitian kualitas pelayanan jaminan dalam mendukung kualitas pelayanan didapatkan hasil sebagian besar setuju bahwa kualitas jaminan sudah baik. Hal ini menunjukkan sebagian besar responden menyatakan bahwa kualitas pelayanan jaminan di Puskesmas Kotagede II sudah baik yaitu sebanyak 94 responden $(77,0 \%)$ dari 122 responden.

Hasil penelitian kualitas pelayanan empati dalam mendukung kualitas pelayanan didapatkan hasil sebagian besar setuju bahwa kualitas empati sudah baik. Hal tersebut menunjukkan sebagian besar responden menyatakan bahwa kualitas pelayanan empati di Puskesmas Kotagede II sudah baik yaitu sebanyak 102 responden $(83,6 \%)$ dari 122 responden.

Hasil penelitian tingkat kepuasan pasien terhadap pelayanan di Laboratorium Puskesmas Kotagede II Tahun 2017 terbagi menjadi 5 kategori yaitu: sangat puas, puas, ragu-ragu, tidak puas, sangat tidak puas.

Tabel 2. Distribusi frekuensi kepuasan pasien

\begin{tabular}{cccc}
\hline No. & Kepuasan Pasien & Frekuensi & Persentase \\
\hline 1. & Sangat puas & 8 & 6,5 \\
\hline 2. & Puas & 39 & 31,9 \\
\hline 3. & Ragu-ragu & 27 & 22,1 \\
\hline 4. & Tidak puas & 33 & 27,0 \\
\hline 5. & Sangat tidak puas & 15 & 12,2 \\
\hline & Jumlah & 122 & 100 \\
\hline
\end{tabular}

Berdasarkan tabel 2. menunjukan bahwa sebagian besar responden yang menyatakan puas dengan pelayanan laboratorium Puskesmas Kotagede II yaitu sebanyak sangat puas 8 responden 
$(6,5 \%)$, puas 39 responden $(31,9 \%)$, ragu-ragu 27 responden $(22,1 \%)$, tidak puas 33 responden $(27,0 \%)$, dan sangat tidak puas 15 responden $(12,2 \%)$ dari 122 responden. Berdasarkan tabel 2 menunjukkan bahwa sebagian besar responden di Laboratorium Puskesmas Kotagede II adalah puas yaitu sebanyak 39 responden $(31,9 \%)$ dari 122 responden.

Hasil uji statistik korelasi kepuasan dengan tiap indikator pelayanan dapat dilihat pada tabel 3 berikut ini:

Tabel 3 hasil korelasi kepuasan dengan pelayanan

\begin{tabular}{cccccc}
\hline No. & Indikator Pelayanan & $\mathrm{n}$ & $\begin{array}{c}\text { Koef. } \\
\text { Korelasi }\end{array}$ & $\mathrm{r}^{2}$ & Sig \\
\hline 1. & Tampilan Fisik & 122 & 0,266 & 0,05 & 0,016 \\
\hline 2. & Kehandalan & 122 & 0,394 & 0,05 & 0,014 \\
\hline 3. & Daya Tanggap & 122 & 0,231 & 0,05 & 0,018 \\
\hline 4. & Jaminan & 122 & 0,244 & 0,05 & 0,015 \\
\hline 5. & Empati & 122 & 0,406 & 0,05 & 0,020 \\
\hline
\end{tabular}

Hasil pengolahan data menggunakan uji statistik korelasi spearman didapatkan hasil dengan tingkat kepercayaan $95 \%$ atau $\alpha=0,05$, setelah dilakukan analisa data didapatkan nilai korelasi spearman sebesar 0,417 berdasarkan rentang korelasi termasuk dalam korelasi sedang dengan nilai signifikansi 0,022 yang lebih kecil dari 0,05 maka hal ini menunjukkan bahwa Ho diterima dan Ha ditolak sehingga dapat disimpulkan bahwa ada pengaruh kualitas pelayanan laboratorium terhadap tingkat kepuasan pasien di UPT Puskesmas Kotagede II Kota Yogyakarta Tahun 2017.

Tabel 4. Hasil kualitas pelayanan terhadap tingkat kepuasan pasien di laboratorium

\begin{tabular}{cccc}
\hline Variabel & $\mathrm{N}$ & $\mathrm{r}^{2}$ & Sig \\
\hline Pelayanan & 122 & 0,417 & 0,022 \\
\hline Kepuasan & 122 & 0,417 & 0,022 \\
\hline
\end{tabular}

\section{PEMBAHASAN}

Pada hasil penelitian ini menunjukkan bahwa sebagian besar responden merasa puas dengan kualitas pelayanan tampilan fisik yaitu yang dibuktikan dengan nilai korelasi sperman sebesar 0,266 berdasarkan rentang korelasi maka korelasi yang didapat termasuk dalam korelasi rendah. Nilai signifikansi yang didapat adalah 0,016 yang lebih kecil daripada 0,05 maka hal ini menunjukkan bahwa Ho diterima dan Ha ditolak yang berarti ada pengaruh antara kualitas pelayanan tampilan fisik terhadap tingkat kepuasan pasien di UPT Puskesmas Kotagede II Tahun 2017. Kualitas pelayanan tampilan fisik (Tangibel) yang diberikan kepada pelanggan seperti fasilitas fisik, perlengkapan, keramahan, akan mempengaruhi tingkat loyalitas pelanggan. ${ }^{4}$

Kualitas pelayanan yang baik akan menghasilkan kepuasan tersendiri bagi pasien. Hal lain yang bisa ditunjukan pada kualitas pelayanan tampilan fisik yaitu letak puskesmas yang berada ditengah kota dan berada dipinggir jalan raya yang memudahkan para pengunjung serta didukung dengan fasilitas laboratorium yang sudah lengkap sehingga keberadaan puskesmas di kecamatan kotagede mempermudah masyarakat untuk mendapatkan pelayanan kesehatan khususnya pelayanan laboratorium.

Pada hasil penelitian ini menunjukkan bahwa sebagian besar responden yang menilai kualitas pelayanan kehandalan yaitu yang dibuktikan dengan nilai korelasi sperman sebesar 0,394 berdasarkan rentang korelasi maka korelasi yang didapat termasuk dalam korelasi sedang. Nilai signifikansi yang didapat adalah 0,014 yang lebih kecil daripada 0,05 maka hal ini menunjukkan bahwa Ho diterima dan Haditolak yang berarti ada pengaruh antara kualitas pelayanan kehandalan terhadap tingkat kepuasan pasien di UPT Puskesmas Kotagede II Tahun 2017. Kualitas pelayanan kehandalan (Reliability) dari pelayanan yang diberikan oleh laboratorium dalam bentuk kecepatan, 
keakuratan dan memuaskan akan berdampak tingginya loyalitas pelanggan terhadap kinerja di laboratorium. ${ }^{4}$

Kualitas kehandalan sudah menghasilkan kepuasan tersendiri bagi pasien.Hal ini ditunjukkan pada kualitas kehandalan yaitu para petugas laboratorium cekatan dalam memberikan pelayanan terhadap pasien sehingga pasien merasa nyaman dan puas terhadap kinerja petugas.

Pada hasil penelitian ini menunjukkan bahwa sebagian besar responden yang menilai kualitas pelayanan daya tanggap yaitu yang dibuktikan dengan nilai korelasi sperman sebesar 0,231 berdasarkan rentang korelasi maka korelasi yang didapat termasuk dalam korelasi sedang. Nilai signifikansi yang didapat adalah 0,018 yang lebih kecil daripada 0,05 maka hal ini menunjukkan bahwa Ho diterima dan Ha ditolak ada pengaruh antara kualitas pelayanan daya tanggap terhadap tingkat kepuasan pasien di UPT Puskesmas Kotagede II Tahun 2017. Kualitas pelayanan daya tanggap (Responsiveness) para petugas laboratorium dalam melayani pelanggan. Ketika pelayanan yang baik diberikan oleh petugas laboratoium akan terbentuk hubungan keluarga sehingga terjalinnya komunikasi yang baik dan efektif. ${ }^{4}$

Kualitas pelayanan daya tanggap menghasilkan kepuasan tersendiri tersebut ditujukkan pada pasien yang merasa nyaman ketika petugas laboratorium tanggap terhadap keluhan pasien mengenai pelayanan, petugas laboratorium melayani dengan baik saat pasien meminta penjelasan terkait pemeriksaan dan petugas laboratorium selalu tanggap terhadap kritik dan saran mengenai pelayanan di Laboratorium Puskesmas Kotagede II.

Pada hasil penelitian ini menunjukkan bahwa sebagian besar responden yang menilai kualitas pelayanan jaminan yaitu yang dibuktikan dengan nilai korelasi sperman sebesar 0,244 berdasarkan rentang korelasi maka korelasi yang didapat termasuk dalam korelasi sedang. Nilai signifikansi yang didapat adalah 0,015 yang lebih kecil daripada 0,05 maka hal ini menunjukkan bahwa Ho ditolak dan Ha ditolak yang berarti ada pengaruh antara kualitas pelayanan jaminan terhadap tingkat kepuasan pasien di UPT Puskesmas Kotagede II Tahun 2017.

Kualitas pelayanan jaminan (Assurance) mencakup pengetahuan, kemampuan, kesopanan dan sifat dapat dipercaya oleh pelanggan. ${ }^{4}$ Kualitas pelayanan jaminan menghasilkan kepuasan tersendiri bagi pasien, hal tersebut ditujukkan pada kinerja petugas laboratorium yang sopan dan juga ramah. Keramahan dan kesopanan petugas laboratorium yang dapat menimbulkan rasa percaya pada pasien karena kepuasan pasien biasanya dikaitkan dengan keramahan dari petugas laboratorium dalam memberikan pelayanan kepada pasien.

Pada hasil penelitian ini menunjukkan bahwa sebagian besar responden yang menilai kualitas pelayanan empati yaitu yang dibuktikan dengan nilai korelasi sperman sebesar 0,406 berdasarkan rentang korelasi maka korelasi yang didapat termasuk dalam korelasi sedang. Nilai signifikansi yang didapat adalah 0,020 yang lebih kecil daripada 0,05 maka hal ini menunjukkan bahwa Ho diterima dan Ha ditolak yang berarti ada pengaruh antara kualitas pelayanan empati terhadap tingkat kepuasan pasien di UPT Puskesmas Kotagede II Tahun 2017.

Kualitas pelayanan empati (Empaty) berkaitan dengan pemberian perhatian penuh kepada konsumen, pemahaman akan kebutuhan pasien, perhatian terhadap kepentingan pasien dan juga kesesuaian waktupelayanan dengan kebutuhan pasien. ${ }^{4}$

Kemampuan puskesmas untuk memberikan perhatian yang tulus terhadap semua pasien tanpa membedakan latar belakang pasien. Perhatian dapat diukur dengan indikator pelayanan, keramahan yang sama tanpa memandang status pasien, dapat memberikan perhatian kepada setiap pasiennya.

Hasil pengolahan data menggunakan uji statistik korelasi spearman didapatkan hasil dengan tingkat kepercayaan 95\% atau $\alpha=0,05$, setelah dilakukan analisa data didapatkan nilai korelasi spearman pada variable tampilan fisik sebesar 0,266 dengan sig 0,016 termasuk kedalam korelasi rendah, varibel kehandalan sebesar 0,394 dengan sig 0,014 termasuk kedalam korelasi rendah, variebel daya tanggap sebesar 0,231 dengan sig 0,018 termasuk kedalam korelasi rendah, variabel jaminan sebesar 0,244 dengan sig 0,015 termasuk korelasi rendah, variabel empati sebesar 0,406 dengan sig 0,020 termasuk kedalam korelasi sedang. maka hal ini menunjukkan bahwa Ho diterima 
dan Ha ditolak sehingga dapat disimpulkan bahwa ada pengaruh kualitas pelayanan laboratorium terhadap tingkat kepuasan pasien di UPT Puskesmas Kotagede II Kota Yogyakarta Tahun 2017.

Pada hasil penelitian ini menunjukan bahwa sebagian besar responden menyatakan puas dengan pelayanan di laboratorium Puskesmas Kotagede II yang dibuktikan dengan nilai korelasi sperman sebesar 0,417 berdasarkan rentang korelasi maka korelasi yang didapat termasuk dalam korelasi sedang. Nilai signifikansi yang didapat adalah 0,022 yang lebih kecil daripada 0,05 maka hal ini menunjukkan bahwa ada pengaruh antara kualitas pelayanan laboratorium terhadap tingkat kepuasan pasien di UPT Puskesmas Kotagede II Tahun 2017.

Kepuasan pasien adalah hasil penilaian pasien berdasarkan perasaannya terhadap penyelenggaraan pelayanan kesehatan. Salah satu indikator kepuasan pasien dapat dilihat dari kinerja petugas laboratorium. ${ }^{5}$ Kepuasan pasien dipengaruhi oleh beberapa hal diantaranya kualitas pelayanan yang mencakup pelayanan tampilan fisik, pelayanan kehandalan, pelayanan daya tanggap, pelayanan jaminan dan pelayanan empati.

\section{SIMPULAN}

Berdasarkan hasil penelitian tentang Pengaruh Kualitas Pelayanan Laboraorium Terhadap Tingkat Kepuasan Pasien di UPT Puskesmas Kotagede II Kota Yogyakarta Tahun 2017 yaitu:

1. Ada pengaruh antara kualitas pelayanan terhadap tingkat kepuasan pasien pada responden yang ditunjukkan dengan nilai korelasi spearman sebesar 0,417 dengan nilai sig 0,022 yang lebih kecil dari 0,05 .

2. Semakin tinggi kualitas pelayanan maka tingkat kepuasan pasien semakin tinggi pula.

\section{SARAN}

Hasil penelitian ini dapat digunakan sebagai masukan bagi puskesmas untuk meningkatkan kualitas pelayanan yang dilihat dari segi tampilan fisik yaitu ruang tunggu yang kurang nyaman dan tempat parkir kendaraan kurang luas dan kurang strategis.

\section{DAFTAR PUSTAKA}

1. Departemen Kesehatan RI. Tentang Penyelenggaraan Laboratorium Pusat Kesehatan Masyarakat. Jakarta: No 37 Tahun 2012;2012

2. Departemen Kesehatan RI. Tentang Penyelenggaraan Laboratorium Pusat Kesehatan Masyarakat. Jakarta: 2010

3. Bustami MS, MQIH. Penjaminan Mutu Pelayanan Kesehatan Dan Akseptabilitasnya. Jakarta: Penerbit Erlangga;2011

4. Kotler. Konsep Penelitian. Jakarta: Grafmido Prasaja;2007

5. Herlambang S. Manajemen Pelayanan Kesehatan Rumah Sakit. Yogyakarta: Gosyen Publishing; 2016 